\title{
A tainted reputation it deserves? Crime in the trotting sector of Dutch horse racing
}

\author{
Angelique Reuselaars ${ }^{1} \cdot$ Frank Bovenkerk $^{1}$ (i)
}

Accepted: 4 May 2021 /Published online: 21 May 2021

(C) The Author(s) 2021

\begin{abstract}
The Netherlands are a small country with an urban underworld history before a serious problem of organized crime has developed since the 1980. The interest of the mob in Horse Race Betting flourished before that time. After a long period of Prohibition since 1911 horse racing (especially trotting) and betting on the results has become a very popular pastime since it was permitted in 1948. Especially during the nineteen seventies and eighties horse races drew a large audience and to a lesser degree they still do. However, bookmaking has always been forbidden since 1911 and that by itself presented in invitation to (organized) crime. Other well-known criminal byproducts of horse racing such as drugging horses, laundering money and matchfixing have been observed but as we measured only to a very moderate degree. The social variety of aficionados for the races is amazing. While doing historical and ethnographic field research at the race tracks we registered a mixture of people of humble origins as well as big entrepreneurs. There were members of the royal family but also well-known criminals. It is amazing to find out to what degree the latter have been accepted by the entire horse racing community.
\end{abstract}

Keywords Crime and animals · Organized crime $\cdot$ Bookmaking · Match-fixing · Drugging race horses $\cdot$ Money laundering $\cdot$ Trotting section of Dutch horse racing

All across the globe, horse racing and betting on the results are associated with any number of crimes, fixing matches, drugging horses, illegal gambling and money laundering. This holds true for Anglo-Saxon countries with a gambling culture where horse races attract much larger crowds and involve a lot more money than in the Netherlands or other countries in Continental Europe except France and Sweden. From the moment organized crime in America has been identified as a special type of crime in the 1920s, this form of criminal conspiracy has played an important role

Frank Bovenkerk

F.Bovenkerk@uu.nl

1 Willem Pompe Institute, University of Utrecht, Utrecht, The Netherlands 
in the world of horse racing. This applies to actual criminal reality as well as the romantic fantasy in crime literature or popular horse movies.

There are two kinds of horse races, running and trotting. In running, the jockey is seated on the horse as it gallops to the finish. In trotting, the horse pulls a twowheeled sulky occupied by a driver who is steering it. Trotting is a special type of movement with the horse moving its legs diagonally. Trotters are much slower than runners but their gait has an elegance all its own.

The distinction between the two is linked to the social history of the class their audience at the races is from (Stokvis 2003). Since the end of the nineteenth century, modern sports such as soccer have first been popular among upper class amateurs. In the late nineteenth century, Clingendaal Racetrack near The Hague had luxurious spacious stables filled with thoroughbred runners usually owned by the aristocracy or distinguished families employing their own jockeys and trainers. The Royal Family had a keen interest in the latest events at the racetrack. The horses were originally from England, France and Germany. The German painter Max Liebermann spent some of his summers from 1870 to 1914 in the Netherlands (in Scheveningen near the Hague beach). He painted the fashionable life style of the era and his scenes featured stables and gorgeous thoroughbred horses. Thanks to successful breeding, the quality of the racehorses was soon greatly improved and at the moment Dutch thoroughbreds are among the finest horses in the world (Minkema et al. 1996).

Holland and Frisian trotting is however typical of folk festivals and annual markets and the short tracks where farmers would race their horses for prizes like a liverwurst or a loaf of raison bread. Owners of the local bars and inns would sponsor trotting and give the winners a Silver Whip (Govers et al. 2000). Later it was factory-owners and prosperous tradesmen who owned the horses. Patricians were now replaced by modern merchants and entrepreneurs. The trainers, drivers and spectators were working class. Trotting became more popular in the twentieth century, races and betting were far more common in the Netherlands for trotting than running. This chapter is mainly focused on trotting. The class differences between the fans of running and trotting are still very much in existence today.

To what extent is Dutch horse racing now affected by crime? After a period of great racetrack popularity in the 1960s, 1970s and 1980s, since 2000 there has been a sharp drop in the Dutch interest in going to horse races and betting on the results. The board of the Dutch Horse Racing Foundation that organizes the competition at the racetracks (the major ones are Duindigt in The Hague and Wolvega in Friesland but there are also numerous local ones) has been wondering ever since 2010 to what extent this resulted from the unfavorable publicity repeatedly referring to criminal tendencies in the sector.

So exactly what kind of criminality have the media observed in the world of horse racing? In 1980 the Dutch TV news program TROS Aktua aired a documentary about the Dutch bookmaking syndicate with a certain Uncle Jan at café Bolhuis near the racetrack in Hilversum where illegal bets could be placed. ${ }^{1}$ In 1997 Zembla, a Dutch tv program known for investigative journalism, had a special on Money and

\footnotetext{
${ }^{1}$ From Tros Actua in 1980. Reference in Andere Tijden, Op het verkeerde paard gewed, May 19, 2013.
} 
Horses and informed viewers that racetracks were no longer a place for a nice family day out. ${ }^{2}$ Shady characters were spoiling the whole atmosphere in the grandstands. A team from the Special Investigation Division probed the illegal bookmaking and Hans Eysvogel, the popular radio commentator on trotting in the 1980s, wondered whether there was any "influence on the racing results." In 2007 Zembla focused on the question of horses being drugged. ${ }^{3}$ Controlled substances had recently been found in the blood of some of the horses and a notorious mobster and horse-owner was given a warning. No one wanted to talk to the reporters. In 2013, the TV program Andere Tijden presented Betting on the Wrong Horse about laundering illegal money by buying up sheets showing racetrack payouts. ${ }^{4}$

The assumption that the decline of trotting was due to a link with the world of crime is certainly not unfounded. One basic risk was probably that more than other sports, trotting depended on the income generated by bets and sponsoring. The racetracks themselves and the state (in the form of taxes) both benefited. How was anyone supposed to believe in the integrity of the state or the racetrack organizers when their income depended on the profits of betting?

In 2003, an opposing voice was heard. In De Gids, a Dutch cultural journal, sport sociologist Stokvis (2003) cited mechanisms that made major fraud less likely. The winnings were not sizable enough to justify the risk of committing fraud, a special committee monitored the races from very close by and filmed them from start to finish and the Foundation had its own disciplinary regulations. Stokvis noted the social control among the owners, trainers and drivers. What is more, he made non-criminal causes behind the decline of the sector seem quite plausible.

The board of the Dutch Horse Racing Foundation assumed the decline undeniably affecting the sport could have something to do with the negative publicity about criminal elements. In 2007, the board wanted an independent assessment of the situation and contacted researchers in the field of criminology. This gave us an opportunity to conduct the kind of research into an economic sector or subculture that is conducted into problems related to organized crime. To examine the high risk sector of horse racing, Reuselaars used the tool kit of ethnography, i.e. on-the-spot observation, interviews, if possible she collected race result statistics and she conducted a survey to see how much fans cared about the tainted reputation of horse racing. She went to various types of trotting races all over the Netherlands, spoke to key figures and people from the audience, and attended criminal court cases.

The first report was written in 2008 and Reuselaars concluded that crime was playing much less of a role than the media claimed. The bad reputation of horse racing at the time was due more to the trotting organizers themselves and the management shortcomings of their Association. In 2020, Bovenkerk provided an update with a new interviews and observations and we use the before mentioned very good television reports. Reuselaars' description of the sport of trotting was confirmed when he consulted people familiar with the branch.

\footnotetext{
2 Zembla, Het geld en de paarden, April 10, 1997.

3 Zembla, Paardendoping, October 28, 2007.

4 Andere Tijden, Op het verkeerde paard gewed, Mei 19, 2013.
} 
There are four aspects to the relation between crime and betting on horse races. 1. Criminals can take advantage of opportunities to open illegal betting sites. This mainly involves a tendency to ignore the prohibition of bookmaking that has applied to the sport of trotting in the Netherlands from the start. 2. Criminals can cheat in otherwise legal gambling operations. They can do so by using exclusive inside information on the anticipated performance of specific horses, pressuring jockeys or drivers to make their horses slow down (by bribing them) or cheating in other ways. 3 . They can drug horses to make them go faster. 4. Organized crime can infiltrate the sector and use it for its own purposes such as laundering illegally obtained sums of money. We would like to examine these aspects in the remainder of this chapter. But first we need to take a close look at the history and institutional design of the trotting sector of Dutch horse racing.

\section{Betting on the results of horse races}

Betting on horse races has been prohibited from 1911 until 1948. There were races and the only possibility to bet was with illegal bookmakers. It certainly helped the horse racing to a criminal image.

Public and commercial gambling were quite restrictively regulated in the Netherlands in the 1964 Betting and Gaming Act, which the state passed for various reasons, one of which was to reduce addiction to gambling. As of 2012, licenses were issued and the system was supervised by the independent Games of Chance Authority. What types of bets were allowed? A Games of Chance Authority folder on horse racing notes that in principle, of course people can bet on whatever they want. "In other countries such as the United Kingdom, people can for instance bet on the election results, the winner of the Song Festival or the date of birth of a new prince or princess. But this is not the case in the Netherlands. There are two exceptions, i.e. betting on the results of sporting events and betting on the results of trotting and other horse races. ${ }^{5,}$

The role horses play in the races and bets differs from the role of other animals in this book. Here animals are not the victims of human acts or abuse, horses do not belong to an endangered species and with the exception of being drugged or whipped at a crucial moment, there are very few serious issues related to their wellbeing as racing animals. One can say though that animals are instrumentalized in that they are forced - after ages of breeding -to move forwards in an unnatural manner and their reproduction is not guided by their own instinct but by the preferences of their breeders. The same holds only true for greyhound and for pigeon racing games. Trotters are expensive and carefully selected by their owners. They are carefully bred for generations and intensively trained. If a horse starts galloping during a race, it is disqualified.

Gamblers assume that to get the best results, they can take advantage of the horses' natural competitive urge. Horses are intrinsically motivated to come in first.

\footnotetext{
${ }^{5}$ From an information folder of the Kansspelautoriteit Weddenschappen, Veilig spelen, 2010.
} 
When horses win, people think they show their pride by moving their ears forward. Horses are the caressed party in this sub-culture. Older Dutchmen who went to horse races in their heyday tell us they are more apt to remember the names of the horses than of the owners, trainers or drivers. In the archives of the Dutch Horse Racing Foundation, the parentage of the trotters and their performance are recorded in the Trotters stud book.

The attraction for spectators lies in the combination of watching an exciting competition and having a chance to bet and win a prize. Spectators can also place bets via the Internet or a bookmaker, but the real spectacle takes place at the racetrack. Anywhere from seven to fifteen times during a game day, a line-up of horses of the same age race a course (the shortest is $1609 \mathrm{~m}$ and the longest $4500 \mathrm{~m}$ ) followed by their sulkies and drivers for two to three minutes. It is very exciting, especially at the end of the race. Changing positions, moving up from the rear and suddenly speeding up, it is spectacular, the enormous competition between the horses. In the last straight stretch of the racetrack, the field fans out and the view of the track can totally change in a matter of seconds. The ones out in front can fall back any minute and the ones at the rear can suddenly speed up. Which one will get to the finish first? Bettors eagerly peer at the finish line to see how the horses they are playing have done.

Since 1964 games of chance are explicitly prohibited in the Netherlands unless they are privately licensed. They have to be games of chance and not hazard games, where winning is totally arbitrary, like at a casino or in the State Lottery. In games of chance based on betting, winning can be influenced by reasoning based upon a certain degree of knowledge. The legal formulation often presented in court cases as the distinguishing criterion is that a game of chance can be licensed "if and when the selection of the winner is determined by a process the participants can generally have little or no influence over" (Berg 1982) and the ruling of the Superior Court in the case of Caritas Soccer Pool. ${ }^{6}$

Starting in the nineteenth century, betting went via bookmakers and the Totalizator or tote board. Bookmakers gave people a chance to place bets at a fixed agreed upon multiple of the invested amount if they won. This amount was called the cote (from the French word for payoff) and could be quite high. Bookmakers were at or near the racetrack and people could gamble at their own risk by placing bets with them. No steps were taken against bookmakers until 1911 and profits were shared with the horse racing agencies to enable the sport to develop (van't Veer 1998). In 1911 the Dutch Parliament passed the Immorality Act prohibiting betting via bookmakers and construing it in criminal justice terms as fraudulent. This meant the end of the popular horse races and many breeders and stables had little choice but to go abroad.

It is not hard to understand that the state has been trying to restrict conduct at risk of getting out of control. But is may seem surprising to us that at the beginning of the twentieth century, the lawful prohibition of betting on horse races was based on moral objections. All games of chance do after all navigate between the human urge

\footnotetext{
${ }^{6} \mathrm{NJ}, 1958 / 329$.
} 
to gamble and the negative consequences of betting, i.e. crime and addiction (see Spapens 2008).

The considerations in the early twentieth century went deeper than that though and included religious objections. It is important to examine this line of reasoning because it illustrates the same social mechanism as the prohibition of the production and sale of alcohol in the United States in 1920-1933. Prohibition in the United States was not mainly aimed at the dangers of drinking but at the social ills caused by spending time at bars in the large cities, where prostitution was practiced, day laborers were picked up whose very existence was undermining the trade unions, and where workers would drink away their wages instead of using them to support their families. All this motivated the Temperance Movement and stimulated its religious objections (see e.g. Behr 1996).

In a thesis written by a Dutch police inspector in Friesland, Vonck (1979) cited the objections voiced a century earlier in Protestant circles. The 1911 prohibition was formulated by the Cabinet headed by the Calvinist theologist and preacher Abraham Kuyper. We should bear in mind that trotting was and still is popular in the northern Dutch provinces, rural North and South Holland and the Bible Belt. In these circles, horse racing was equated with gambling and viewed as an affront to the holiness of fate. God's intervention was not to be wrongfully used for profane purposes. Vonck researched the sub-culture of people who bet at the racetracks around the late nineteenth and early twentieth century. People's urge to gamble was viewed as a passion that needed to be properly channeled.

In essence, a bookmaker who accepted a bet was speculating that the horse would lose. He had a personal interest in a negative result because then he didn't have to recompense any winnings, and this could have a criminogenic effect. Based on information he had access to from his daily contact with the owners, trainers and drivers, he could help fate along. A special favorite could be encouraged to be "let go" at the last minute. Just before the race, he could spread the rumor that a certain horse was "a bit out of sorts." During the race, a driver could get his horse off balance by not correcting its tendency to gallop, or amidst the other trotters, he could have himself closed in during the race. He could mess with the harness in a way that would irritate the horse, he could distribute the horse's energy over the course in the wrong way so the horse would be out of breath before the race was over, and nothing was as effective as giving a horse a bucket of water to drink just before the race began. All these kinds of sabotage are hard to prove because race results always depend on unpredictable factors, the weather, the condition of the track, how the driver feels, the starting number, the condition the horse is in.

At the time of his study, the 1970s, Vonck counted about eighty people who were denied entry at the racetrack because of bookmaking. Although they generally called themselves merchants or businessmen, most of them had a criminal record. They made bets orally or wrote them down in notes incomprehensible to the outside world.

When someone who placed a bet won and came to collect the winnings, the bookmaker was still not ready to acquiesce. He would invite the fortunate winner to double his profits by making just one more little bet, for example to guess what make of car would be the first to turn the corner. They could also play a game of 
cards (with a deck of marked cards) or a game of dice (with loaded dice). There were housewives who came to complain their husbands had gambled away their whole week's wages. Vonck criticized his fellow police officers in Groningen for failing to notice this as a crime.

Nowadays the reasons for prohibiting bookmaking at the time make a rather outdated impression. In retrospect we can also ridicule the nonsense of Prohibition in the United States. Forbidding a product there is a great economic demand for when the majority of the population does not view supplying it as a crime provokes a brand of criminality it is hard to get under control. One of the bookmakers who could usually be found on a race day at Duindigt was Big Harry Engels. He was once issued a bookmaker's license in Belgium, where bookmaking was allowed. He explained to reporters from the Zembla TV program Money and Horses exactly what students of law in Continental Europe learn is the difference between criminal acts according to statutory law (crimes mala in se) and law as principle (crimes mala prohibita). "I am not hurting anyone," Engels said to us, "it is just something I am not allowed to do because it is against the law. I never did anyone any harm."

In the last quarter of the nineteenth century, the Totalizator was introduced as a second option for organized betting. The Totalizator is a French invention now in use at racetracks all across the globe. It works with a system of pari-mutuel betting and wagering. In this system, all the bets of a particular type are placed together in a pool. Taxes and house takes or vigorish are then deduced and the remainder is divided among the winners. Unlike most other forms of betting, at horse races betters are wagering against each other (Spapens 2008: 25).

This form of betting was also prohibited up until 1948. Since then it has been allowed and was legally regulated by the 1964 Betting and Gaming Act. It is important to note that despite the acceptance of the pari-mutuel system, booking via bookmakers is still illegal. Some people nonetheless have a clear preference for betting through bookmakers. The bets are made informally and without any written records, it is possible to wager large amounts of money and not necessary to spend $29 \%$ of the cote on the games of chance tax.

After the economic recession began in 1981, the Totalizator was privatized. The British firm Ladbroke stepped in, but the profits were disappointing. This was followed by years of unclear transfers from one private party to the other. If the competition was legal, a betting license was issued to one company that would organize a Totalizator (Tote). In 2010, the Dutch license to operate as the sole Totalizator organizer for horse races was issued by the Gaming Authority to Runnerz. In 2010 Runners became part of ZEbetting \& Gaming Netherlands Ltd, which in turn is part of ZEturf France Ltd, an international firm in thirty countries that is run from Luxemburg. ZEturf France Ltd advertises that its payoff percentage of $75 \%$ for the various systems (Soccer Toto, State Lottery etc.) is the highest of all the lotteries in the Netherlands. In addition to the sales counters at the large racetracks (Wolvega and Duindigt) and the option of betting on the Internet, there are another thirty locations all across the Netherlands where bets can be made, particularly in the northern provinces and North Holland. Based on an agreement between the Foundation for the Netherlands Trotting and Running Sport and the agency that had the license at 
the time to organize betting on horse races, $7 \%$ of the turnover goes to the sport of horse racing.

We would like to give a brief account now of the history of the Duindigt racetrack on the outskirts of The Hague and right next to Huis ten Bosch Palace, where the Dutch Royal Family lives. We also have a thing or two to say about the deviant conduct of some of the racetrack patrons. This does not apply nearly as much to Victoria Park, the country's largest racetrack in the Frisian hamlet of Wolvega. In 1991 a large trotting center was opened there that was to overshadow all the other racetracks in the Netherlands with its total size and its track. The date was unfortunate though because of the sharp decline at the time in the sport of horse racing, running and trotting alike. But in 2010 a private businessman breathed new life into the branch by establishing an international connection in France. In the following period, the position of Victoria Park was totally restored. Organized by PMU (Pari Mutuel Urban, the French horse betting authority), the French can bet online on Dutch racetrack results. Especially during the semi-nocturnal Friday evening races (when (when there are no races in France and workers have just been paid and go for a drink before supper to a bar where the Wolvega horse races are on television), there is a huge turnover, unprecedented in the Netherlands, and this raises the payoffs. As time passed, the French knew more and more about which Dutch horses were the best. The management at Victoria Park does its best to adhere to all the rules. In an interview, one of the commentators at the races in Friesland says the management tries very hard to avoid being associated with crime in any way.

\section{Four Illegal gambling options}

\section{Again the 'problem' of bookmakers}

When legal horse racing re-opened in 1948, it wasn't long before bookmakers reappeared openly on the scene. This was a serious problem for the police because bookmaking was popular but still prohibited. It was easy to attribute the victories of outsiders among the horses to the bookmakers and they did sponsor the branch with their profits, much as they had done legally before 1911. As Rijken (1968) notes, "hundreds of bookmakers," or at any rate about eighty of them circulated among the horse racing fans in these prosperous years. It was part of the bookmakers' job to always be on the lookout for information about the trotting field, the horses' condition and anything else that could facilitate predicting the race results. They were especially focused on the leading horses that were not doing particularly well at the moment. The bookmakers' wagers were based on their own personal interest in a particular horse losing the race. They had a few assistants walking around who did the actual transactions. This enabled the bookmakers themselves to stay out of sight. At a very low level, this strategy resembled the customary one in organized crime where bosses in operation stay in the background as much as they can. The bookmakers' weak point was when someone bet on an unexpected horse and won. Of course they had to pay out the cote agreed on. They would cover themselves by betting on the horse on the Totalizator, thus lowering the cote. 
Fifteen years later, Zantinge (1984) similarly estimated their number - including the ones at the bars just outside the racetrack- at "a few hundred." Vonck (1979) was more cautious and did not estimate their number, he just counted the bookmakers who were denied entry to the area after a police raid and arrived at eighty. Zantinge referred to forty-five of them. The group of bookmakers included a few individuals with a certain status in the underworld. They were bookmakers and trotter-owners at the same time.

In a report published by Ernst \& Young Forensic Services (2001: 62-65) shortly after the turn of the century, the authors estimated the dramatic decline in horserace bookmaking in the Netherlands at a few hundred players and about eight bookmakers with a joint gross annual turnover of 440,000 guilders, which would now be less than half that amount in euros. They noted that bookmaking had become a marginal activity. There is a big difference in these figures and that means the authors themselves didn't really know either. None of them provided any backing for their estimations. But it is clear that there has been a sharp decline in trotting since the 1980s. This mainly had to do with changes in the games of chance market and the increased spectator interest in other sports, mainly soccer.

Another specific reason for this sharp decline was also mentioned on the TV programs referred to at the beginning of his chapter. In the 1980s a team of eight investigators was appointed by the General Inspection Division of the Dutch Ministry of Farming and Fishing to identify bookmakers and catch them taking bets using a tactic of stalking and harassing. Not that they had much trouble finding gamblers among the spectators who were willing to snitch on them. The investigators were merely compliance officers and their power did not extend much further than denying bookmakers entry at the racetracks, which were private property. Police reports were drawn up on various occasions, but not very often led to actual court cases. Just the common knowledge that there were investigators among the spectators had a preventive effect. After this step was taken, bookmakers could still be seen busily gesticulating to their minions or players in the audience from higher spots a certain distance from the track itself, as if they were familiar with the refined codes of British bookmakers. In the past twenty years, a modus vivendi has developed between officials and bookmakers. At the moment, there is no longer any evidence of this monitoring of bookmakers. So one attraction of betting at the racetrack has been virtually eliminated. The comment was made on the TV program Andere Tijden that "In the end they had decent, law-abiding crowds but no turnover."

\section{Match fixing?}

Horse racing, running and trotting alike, is easily susceptible to illicit influencing of the results if drivers make certain agreements with each other. They can be acting on their own initiative or be bribed to do so by third parties. There is plenty of match fixing in any number of sports (soccer, tennis, boxing) and horse racing is no exception in the Anglo-Saxon world, Italy or France. Very little notice has been taken of match fixing in the Netherlands (Olfers and Spapens 2013), there have not been any large-scale bribery scandals and research studies have yet to be launched. 
In our contact with trainers and drivers, we were assured that match fixing rarely occurs in the Netherlands and that has to do with the Dutch attitude to winning. Former jockey $\mathrm{G}$ noted that "we all do our very best" and driver $\mathrm{C}$ said "drivers fight to win." The tension before and during the races is overwhelming. Just sniffing the wind, the smell of the horses, hearing the clippity-clop of the hooves, vying for a good position, speeding up and experiencing the battle between the horses are such exciting moments that the drivers and jockeys are barely interested in nefarious proposals. Everything is focused on getting their horse to perform well. There is a system of performance monitoring that enables the Horse Racing Committee that drives in a car alongside the horses to check all their movements during the race. The details of their appearance did not used to be described but it is apparently necessary nowadays.

A distinction needs to be drawn between the internal unwritten rule that "someone who knows something can predict the race results" and race fixing. Anyone who wants to seriously compete has to have inside information. Everyone who places bets is interested in information and no one blames anyone else for their interest. We constantly see at the racetracks that everyone is looking for the golden tip. This is an integral part of the sport and is not classified as race fixing.

It is relatively simple to follow the race results over a longer period of time and see whether there is match fixing going on. The assumption is that races are fixed to deliberately allow horses that are likely to win to lose a race to increase the payoff on the next race that they do win. In 2007 our colleague Henk Elffers analysed a series of results of the main races horses took part in at least ten times (see for details Reuselaars 2008: 38-41). The statistical problem is then to explain the alternating good and less good results. Elffers concluded that considering the averages for all the racetracks over the past few years (before 2008), there is no evidence of race fixing.

\section{Drugging horses}

Since 2000, there have been several smaller scandals related to drugging horses. By smaller we mean the scandals could not be compared to the enormous ones in France or the Anglo-Saxon countries. In 2016 a famous French trainer, Fabrice Souloy, boosted the performance of his horses in Scandinavia by administering Cobalt was temporarily dismissed from his position. At the moment (2019), there is a case in the United States (Kentucky Derby) where no fewer than twenty trainers and veterinarians are on trial for cruelty against an animal involving the extremely successful horse Maximum Security that has earned millions of dollars. Compared to this, the Dutch cases are laughable.

There was a dispute in the Netherlands during the 1980s about the origins of a minimal amount of heroin in the blood of a racehorse. Had it been injected or did it come from the poppies that were mowed with the grass in the meadow and then fed to the horse? The fact remains though that there are still two problems. It is not a good idea for the same veterinarians who supervise the health of a horse and can thus administer medication to also do the monitoring. Any substance that is not 
naturally found in the body of a horse should not be in evidence there during a race, even if it is a medicine or pain killer. The idea this is based on is that the animals themselves cannot choose whether they want it or not.

There have however been serious disciplinary cases. Nine cases came before the Disciplinary Board in 2005. Morphine was found in the urine of the successful stallion Willem Boko in 2007. The famous trainer Hugo Langeweg Sr was charged at the time and on other occasions as well and sentenced by the Disciplinary Board (De Volkskrant, 6-10-2007). This topic is difficult to research. The police cannot act because these cases are dealt with by the Disciplinary Board.

\section{Associations with the mob}

During our research at the racetracks, we met a community of racing fans who know each other reasonably well and many of whom are strikingly well informed about the quality of the various horses. The Foundation for the Netherlands Trotting and Running Sport also supplies information in this connection, especially on the recent performance of the horses, to preserve the nature of fair wagering in contrast to gambling. The standard answer to our question on who these people are exactly is "anyone and everyone from beggars to princes." First the players. Everyone who bets on the horses agrees that spectacular amounts of money are sometimes won, but also that in the long run, it doesn't lead anywhere. One thing the players have in common is that they are generally self-employed ("I couldn't work for a boss") and come from the world of easy money. The group includes tradesmen, often butchers or flower dealers. What is striking is the relatively large number of women who are enthusiastic about horse racing.

The breeders, trainers and drivers are essential to horse racing and to safeguarding its integrity. Their level of ethics were found impressive at our first research round. It was no simple matter to enter these professions, the threshold was high. Anyone who wanted to become a professional jockey or trainer needed to attend a special training course. As a result of the decline of horse racing, this has now changed into a shorter education and a simpler exam. As The stables are spic and span and nice and quiet, the boxes are clean. far as we could see, the trainers and drivers adhere to a high ethical standard. According to them, there is barely any race fixing. Not that it would be that much trouble to arrange a race without anyone noticing, but as a scion of a long line of drivers explained, if I were to accept a proposal like that, "my father would break both my legs."

Many of today's horse racing fans are from families that were already interested in horses and could afford to own and take good care of them. The attachment to the world of horses is also evident from the relatively large number of volunteers who - in this age of declining incomes-are willing to help keep the sport going.

Associating horse racing with organized crime mainly has to do with to the reputations of the horse and stable owners, especially in the US. This association goes back more than a hundred years to before the start of the twentieth century and the reputations were mainly established in the large cities of the United States. Ever since information on horse races could first be passed on by telephone, there 
was the option of organizing off-track betting via control over the channels of communication. Gangsters with a reputation like Arnold Rothstein and Frank Erickson made their careers this way. After Prohibition stopped serving as the main source of income for the Mob in 1933, some gangsters went on to organize bets on the horse races because this was not outlawed by some of the local governments (van't Veer et al. 1993: 63).

Back to the Netherlands. For the simple reason that buying and keeping racehorses and paying capable trainers and jockeys cost much more than could possibly be earned from the prizes, we know the horse and stable owners did not acquire their fortunes at the racetracks. In the Netherlands, it was initially horse breeders who worked their way up to owning the horses. They were often people of humble origins who put everything aside for their hobby, their racehorse. The better the horses were and consequently the more expensive, the more they could help their owners establish a position in society. The Dutch Association of Racehorse Owners includes an impressive number of self-made entrepreneurs with their own businesses. Usually it is a matter of new money. They are ship-building magnates, food importers, real estate speculators and the owners of supermarkets, hotels, restaurants and bars. At the Business Class, the restaurant in Duindigt, we sometimes see piles of money in rubber bands quasi nonchalantly sticking out of various pockets.

Amidst all these company directors, regular gangsters are not apt to make much of an impression. But they do command respect in their own social circles. In most of the literature on organized crime, the criminals' desire to make a lot of money is automatically accepted as their only motive. In the more detailed analyses, however, other incentives also play a role. The organized crime bosses also want power, prestige, honor, respect, especially the respect of the local community, and a nice way to spend their free time (cf. Cockayne 2016). They can boost their prestige by acting as entrepreneurs and sponsors in the entertainment industry and in sports. The American mob choose the world of their favorite sports and in the United States in the twentieth century, it was all about boxing, baseball and horse racing (Haller 2013). The stereotypical mobster in the HBO series on Tony Soprano shows there love for horses. Tony shows his affection by laying down next to his sick animal 'PyO-May', gently stroking her neck and telling her that every thing will be allright. ${ }^{7}$

The American example was followed in the Netherlands by whoever wanted to make a name for himself after World War Two as penoza, a Yiddish word that literally means a way to earn a living and is used to refer to members of the urban underworld with its own sub-culture. The penoza consisted of pimps, vagabonds, unregistered cab drivers, thieves, cigarette smugglers, fences, card sharps, black marketeers (World War Two) and so forth. There were also the gambling penoza that victimized pedestrians with a simple game of cups and balls. The post-World War Two generation in Amsterdam initially focused on gambling at casinos and prostitution. Starting in the 1970s, they increasingly turned to producing and selling drugs. Barely anything is left nowadays of the oldest segment of this generation because the ringleaders either died or murdered each other (Spapens et al. 2016).

\footnotetext{
7 The Sopranos 44th episode in the fourth season.
} 
In the Netherlands, the penoza liked soccer, kick boxing and horse racing (there were real horse lovers), especially in the past. Sponsoring these sports earned them prestige. And the casinos were popular too. In the racetrack heyday, the penoza of Amsterdam frequented the one at Duindigt, and not primarily to earn money but for the recognition and to enjoy themselves. In the top years of horse racing the main prizes, the Golden Whips, were awarded by none other than Queen Juliana's husband His Majesty's Prince Bernhard! Starting in 1955, he did it thirty-seven times. The last time was in 1994. The royal family's interest stopped after the publicity about a dispute at the Board of the Dutch Trotting and Running Sports Association and the warning that the royals could be confronted with horse lovers of ill repute. Ever since the 1990s, the ceremonial role has been taken over by other dignitaries such as the Queen's Commissioner. Of course horse-owners were interested in the prize, but their real interest was in winning and having their photograph in the newspapers with Prince Bernhard. It was all about prestige, and not primarily money. We would like to mention three of the underworld ringleaders who frequented the racetracks and are known to everyone in the Netherlands.

Maup Caranza began as a dealer in car wrecks. In what his biographer called a puzzling rise (Pelt 2019: 386-387), he became a real estate speculator and magnate. Starting in the mid-twentieth century, he owned the huge entertainment center on Rembrandt Square in the middle of Amsterdam. He gave a few top thoroughbred horses to his wife Rika ("a woman has to have something to do") and did his best to get her favorite horse Manza Buitenzorg chosen as Trotter of the Year in 1976 (Pelt 2019: 232-233). She expanded her stable to include a stud farm of seventeen stallions and they were trained by none other than the renowned Jantje Wagenaar. Caransa has been instrumental in using his talents as a businessman when making peace when a conflict arose within the organization of horse owners.

Another well-known personality was Gijs van Dam, who began his career as ' the best taxi driver of Amsterdam' developed into one of the first large-scale soft drug importers to the city in the 1970s. In the 1980s he commanded respect with his beautiful horses, a top trainer (Vergay) and a driver who ventured to take part in the French races. He once told a crime reporter who interviewed him that it was all about collecting tippies, golden tips from the stables (Korterink 2017). His conduct was totally focused on gaining status. After a horse of his won a race, he looked for a an opportunity for a photograph with a member of the royal family, unsuccesfully. The third horse lover was Cor van Hout, who played a leading role in the spectacular kidnapping of beer tycoon Freddy Heineken and his chauffeur Ab Doderer in 1983. Except when they were at a bar, he and his friend Willem Holleeder spent a lot of time at the racetrack and they were always gambling. Cor can Hout was a popular openhanded man who owned any number of racehorses including the renowned Golden Sand. After they served their prison sentences for the kidnapping and spent eight million of the total of thirty-five million guilders of Heineken ransom money that was never found, one of his criminal periods ended with his next arrest. A preliminary judicial investigation was launched against Cor van Hout in 1995 concerning his investing the profits of criminal activities in trotting races and the gambling and sex industries (Van de Pol 2019, 37). Golden Sand won the Dutch Championship in 1997. The national anthem was played and there 
was a photograph in the newspaper. Cor van Hout was arrested a day later, on October 6,1997 , suspected of running a criminal organization importing hashish on a huge scale (Korterink 2017,179).

\section{Money laundering}

The activities of horserace fans can easily be converted for purposes of money laundering. In a Justice Department survey on how the underworld and the legitimate side of organized crime are inter-related (Regional Information and Expertise Center 2010), the horse trade is an example of a branch used to explain away rises in wealth or fluctuations in value. After all, a horse can be purchased for a few thousand euros but after it is trained as a racehorse, a value increase of thousands of euros is not unrealistic. If it is injured, a horse is worth as much as a local butcher will give for it. It is difficult for the authorities to determine whether transactions are conventional or not. The world of horse lovers is quite understandably very closed about issues like this. In its pricing heyday in the 1970s and 1980s, the sport of horse racing was probably used for laundering illegally acquired wealth. No one was doing any serious monitoring at the time and the authorities didn't really know how to. There a no figures available. Nowadays the Fiscal Information and Investigation Division of the Tax Department is the only supervisory agency that is widely respected. Wealthy company directors who own horses also managed to have fiscal options for deducting the expenses for their horses or stables from their company's taxes. In some cases, company-owners evade Tax Department attention by appointing a manager so wealthy his fortune is not in question. And on a smaller scale, in the gambling world there are people who buy up the lottery tickets of the real winners. However, on the whole horse owners are not rich at all.

In the world of horse-owners, it is not in anyone's interest to question where the money is coming from. Everyone tolerates well-known underworld kingpins and is friendly to them. Horse-owners do not carefully pick and choose new members. "The doors are always open for the owners," one trainer/driver says. No one checks their antecedents. One Sunday afternoon, we asked about eighty people in the grandstands at Duindigt racetrack whether they thought others were staying away because of the criminality, especially the reputation of the penoza who were hanging around. The tolerance level appeared to be high and quite honestly, some of them thought it would be kind of exciting to see underworld celebrities they knew from the newspapers close up like that.

\section{In closing}

After the turning point in the early 1980s, horse racing and betting on horses lost much of the popularity they had had after World War Two. The decline of this sub-culture didn't have that much to do with the sport itself. Fashions come and go and there were other sports, especially soccer, that took its place in the public eye. The attraction of betting and spending a nice day with the whole family 
at the horse races played less of a role now that games could be played online. The entertainment industry had so much more to offer and the vast assortment of games and exciting heroes on television pretty much eliminated the competition. There are so many other options nowadays for betting and gambling. A specific drawback of horse racing is that it is so poorly organized. After so many bookmakers went out of business and Totalizators were privatized, these functions became less and less profitable and kept being passed on from one party to another. As a result, there were no longer enough racehorses to produce a nice wide range on the track and the race results were increasingly predictable. The former glory of the racetrack in Duindigt is clearly fading and only the impersonal online bets on the races at an international distance from the Frisian town of Wolvega are still properly operating.

Here we only researched the extent to which the criminal reputation linked to horse racing could be held responsible for its decline. Not much was found in the Netherlands comparable to the huge scandals in the Anglo-Saxon world with fixing matches and drugging horses. The Dutch authorities successfully put the bookmakers out of business. It is true that in other countries (UK and France), bookmaking is still allowed and accounts for a great deal of the attraction. This has been lost in the Netherlands. The horse races provided ample opportunity for laundering illegally acquired sums of money. In the tiny world of horse-lovers where everyone often knows everyone else, this is not viewed as a big risk. That will change if the authorities continue hunting down illegal riches. Lastly, this chapter focuses on the extent to which the horse-racing sport's association with the underworld or penoza has harmed the branch. We barely found any evidence of this. On the contrary. In fact we think maybe a shady reputation only enhances the charm of horse racing!

\section{Declarations}

Human and animal participants This article does not contain any studies with human participants or animals performed by any of the authors.

Conflict of interest The authors declare that they have no conflicts of interest.

Open Access This article is licensed under a Creative Commons Attribution 4.0 International License, which permits use, sharing, adaptation, distribution and reproduction in any medium or format, as long as you give appropriate credit to the original author(s) and the source, provide a link to the Creative Commons licence, and indicate if changes were made. The images or other third party material in this article are included in the article's Creative Commons licence, unless indicated otherwise in a credit line to the material. If material is not included in the article's Creative Commons licence and your intended use is not permitted by statutory regulation or exceeds the permitted use, you will need to obtain permission directly from the copyright holder. To view a copy of this licence, visit http://creativecommons.org/licen ses/by/4.0/.

\section{References}

Behr E (1996) Prohibition. Thirteen years that changed America. Arcade Publishing, New York 
Berg C (1982) Wedden op paarden (Betting on Horses). Economisch-Statistische Berichten 1982: 1362-1365

Ernst \& Young Forensic Services (2001) Verkeerd gokken, Oriënterend onderzoek naar aard en omvang van illegale kansspelen in Nederland, (Betting wrong, exploratory study on the nature and extent of illegal games of chance in the Netherlands). The Hague/Amsterdam

Cockayne J (2016) Hidden power the strategic logic of organized crime. Oxford U.P, New York

Govers J, van der Lubbe RQJ, Minkema D, Rijkers Meinen L (2000) Van 'Draverssport' tot AEV. Kroniek van 75 jaar drafsport in Nederland, (From the sport of trotting to the AEV. Chronicle of 75 years of trotting in the Netherlands), Publication of the General Association of Owners "The Sport of Trotting",

Haller MH (2013) Organized crime in urban society: Chicago in the twentieth century, in: Yeager MG (ed.): Illegal Enterprise, the Work of Historian Mark Haller, University Press of America Inc., Lanham etc.

Korterink HJ (2017) Cor. Het levensverhaal van een beroepscrimineel (Cor. the life story of a professional criminal). Just Publishers

Minkema D, Jager K, Frerichs D (1996) Dravend door de tijd. Geschiedenis van de Nederlandse draverfokkerij (Trotting through time. History of dutch trotter breeding), Kerckebosch Ltd, Zeist

Olfers M, Spapens ACM (2013) Matchfixing in Nederland: de aard en rijkwijdte van het probleem, de risico's en aanpak (Match fixing in the Netherlands: The nature and range of the problem, the risks and how it is tackled). Tilburg University

Pelt W (2019) Maup Caransa, vastgoedmagnaat van Amsterdam (Maup Caranza, Amsterdam Real Estate Tycoon). Prometheus

Reuselaars ADCE (2008) 'Race fixing', Prestatiebewaking binnen de professionele Nederlandse drafen rensport (Race fixing. Performance monitoring in professional dutch running and trotting horse races). Criminology dissertation. University of Utrecht

RIEC (Regional Information and Expertise Center) (2010) Verwevenheid van onder- en bovenwereld bij georganiseerde misdaad, Een overzichtsstudie: aard en oorzaken (Links between underworld and legitimate businesses in organized crime. A Survey Study: Nature and Causes)

Rijken AJL (1968) Het geoorloofd en ongeoorloofd wedden bij paardenrennen en harddraverijen (Authorized and unauthorized bettng at horse running and trotting races). Algemeen Politieblad: 147-154

Spapens T (2008) Crime Problems Related to Gambling, in: Spapens T, Littler A, Fijnaut C (eds), Crime, Addiction and the Regulation of Gambling. Martinus Nijhoff Publ. Leiden: 19-51

Spapens T, Kolthoff E, Stol W (2016) Georganiseerde misdaad in de $21^{\mathrm{e}}$ eeuw. Tijdschr Criminol $58(2): 3-18$

Stokvis R (2003) Is er corruptie bij het harddraven in Nederland? (Is there corruption in the trotting sport in the Netherlands?). De Gids 166(2003): 894-908

Van de Pol W (2019) Holleeders onderwereld. Onthullingen uit de politiedossiers (Holleeder's underworld. Disclosures from the Police files), Karakter Uitgevers Ltd., Uithoorn

van 't Veer A (1998) Spelregels (Rules of the game), Gouda Quint, Deventer

Veer, Moerland H, Fijnaut C (1993) Gokken in drievoud. Facetten van deelname, aanbod en regulering (Gambling in triplicate. Aspects of participation, supply and regulation), Gouda Quint, Arnhem

Vonck FJ (1979) Het geoorloofd - en het ongeoorloofd wedden bij harddraverijen en paardenrenen, (Allowed and prohibited gambling at trotting and horse races) Thesis, College for Police Investigators, Stiens

Zantinge H (1984) Bookmakerij Kwaad dat bestrijding verdient (Bookmaking. An evil that deserves to be combated). Algemeen Politieblad: 283-290

Publisher's note Springer Nature remains neutral with regard to jurisdictional claims in published maps and institutional affiliations. 